\title{
Aquatic Insect Biodiversity and Water Quality Parameters of Streams in Northern Thailand
}

(Kepelbagaian Biologi Serangga Air dan Parameter Kualiti Air Anak Sungai di Utara Thailand)

\author{
T. PROMMI* \& A. PAYAKKA
}

\begin{abstract}
Biodiversity of aquatic insect and physicochemical water quality parameters in Mae Tao and Mae Ku watersheds were assessed bi-monthly from February 2011 to February 2012. A total of 59 families representing 9 orders were recorded. At order level, Trichoptera was found at the highest frequency in total abundance (45.75\%) followed by Ephemeroptera (18.06\%), Hemiptera (13.45\%), Odonata (9.62\%), Diptera (8.17\%), Coleoptera (4.6\%), Megaloptera (0.17\%), Lepidoptera (0.11\%) and Plecoptera (0.07\%). The family Hydropsychidae was the most prominent and the most abundant aquatic insect taxa followed by Chironomidae. Water temperature, dissolved oxygen and ammonia-nitrogen were similar at all sampling stations. Significant variations in $\mathrm{pH}$, electrical conductivity, total dissolved solids, sulfate, nitrate-nitrogen and alkalinity were found at all sampling stations. Taxa richness and diversity index significantly correlated with dissolved oxygen, sulfate, nitrate-nitrogen and ammonia-nitrogen $(\mathrm{p}<0.05, \mathrm{p}<0.01)$. Physicochemical data and biological data showed that mostly the surface water quality in Mae Tao and Mae Ku watersheds were within Type III of The Surface Water Standard for Agriculture and Water Quality for Protection of Aquatic Resources in Thailand.
\end{abstract}

Keywords: Aquatic insect; diversity; physicochemical variables; richness; watershed

\section{ABSTRAK}

Kepelbagaian biologi serangga akuatik dan parameter kualiti air fizikokimia dalam tadahan air Mae Tao dan Mae Ku dinilai setiap dua bulan sekali dari Februari 2011 hingga Februari 2012. Sejumlah 59 keluarga yang mewakili 9 order telah direkodkan. Pada peringkat order, Trichoptera telah ditemui dengan kekerapan tertinggi (45.75\%) diikuti oleh Ephemeroptera (18.06\%), Hemiptera (13.45\%), Odonata (9.62\%), Diptera (8.17\%), Coleoptera (4.6\%), Megaloptera $(0.17 \%)$, Lepidoptera $(0.11 \%)$ dan Plecoptera (0.07\%). Famili Hydropsychidae adalah yang paling menonjol dan yang paling banyak takson serangga akuatik diikuti oleh famili Chironomidae. Suhu air, oksigen terlarut dan amonia-nitrogen adalah sama di semua stesen pensampelan. Perubahan ketara di dalam pH, pengaliran elektrik, jumlah pepejal terlarut, sulfat, nitrat-nitrogen dan alkali ditemui di semua stesen pensampelan. Kekayaan takson dan indeks kepelbagaian dengan ketara berkorelasi dengan oksigen terlarut, sulfat, nitrat-nitrogen dan amonia-nitrogen ( $<<0.05, \mathrm{p}<0.01)$. Data fizikokimia dan biologi menunjukkan kebanyakan kualiti air permukaan di tadahan air Mae Tao dan Mae Ku adalah Jenis III dalam Piawai Air Permukaan untuk Pertanian dan Kualiti Air untuk Perlindungan Sumber Akuatik di Thailand.

Kata kunci: Kekayaan; kepelbagaian; pemboleh ubah fizikokimia; serangga akuatik; tadahan air

\section{INTRODUCTION}

Aquatic insects are a group of arthropods that live or spend part of their life cycle in water bodies (Arimoro \& Ikomi 2008; Pennak 1978). They are of great importance to the aquatic habitat where they are found, hence, their presence in water bodies serve various purposes: Serve as food for fish and other invertebrates, others act as vectors through which disease pathogens can be transmitted to both humans and animals (Chae et al. 2000). Most importantly, aquatic insects are very good indicators of water quality since they have various environmental disturbance tolerance levels (Arimoro \& Ikomi 2008). Some are very vulnerable and sensitive to pollution, while others can live and proliferate in disturbed and extremely polluted waters (Hepp et al. 2013; Merritt \& Cummins 1996). Anthropogenic activities of humans such as releases from domestic sewage, run-off from agricultural lands, laundering into streams and mining activities. Most water bodies have consequently been subjected to increasing pollution loads, affecting greatly their quality and health status. This undoubtedly alters the physicochemical properties of water e.g. temperature, dissolved oxygen, alkalinity, phosphates, nitrates and metal concentrations. Variations in these water properties greatly influence the distribution patterns of aquatic insects in the water since some of them are highly sensitive to pollution while others are somewhat tolerant or completely tolerant to pollution and environmental disturbances (Hepp et al. 2013).

Many methods have been developed to analyze impairments to water quality. Amongst these, physical parameters (such as stream bank erosion, turbidity, sedimentation, siltation, flow patterns, water temperature, 
riparian cover and debris) and chemical parameters (such as dissolved oxygen, biochemical oxygen demand, $\mathrm{pH}$, alkalinity, hardness, nutrients, metals and organic compounds) analyses have been investigated to assess the quality of water (Aweng et al. 2011; Zarei \& Bilondi 2013). Unfortunately, because sampling and analysis are expensive and because concentrations of pollutants vary greatly with time and location, physical and chemical monitoring alone often cannot detect non point source pollution problems. In contrast, biological monitoring gives an indication of past conditions as well as current conditions (Resh et al. 1996; Suhaila et al. 2014). The additional integration of biological parameters to physicochemical assessments has proven to be a more complete method to fully assess pollutant effects in aquatic ecosystems most particularly in lotic systems (Oliveira \& Cortes 2006). Bioassessment provides more reliability in evaluating the presence and impact of pollutants because lotic systems are subjected to flushing during storm events and contaminants may be swept away without any apparent effect (Borisko et al. 2007; Buss \& Vitorino 2010). The most important biota used for bioassessment studies are benthic macroinvertebrates. Benthic macroinvertebrates have been used in numerous bioassessment studies indicated their importance as bioindicators and the endless advantages they offer in evaluating the presence and extent of environmental pollutants (Rosenberg \& Resh 1993; Xu et al. 2014).

Among benthic macroinvertebrates, aquatic insects are one of the most common groups of organism used to assess the health status of aquatic ecosystems (Rosenberg $\&$ Resh 1993; Xu et al. 2014). They are useful indicators, because they represent a diverse group of long living sedentary species that react strongly and often predictably to human influences on aquatic systems (Cairns \& Prall 1993). Some aquatic insects respond to specific changes in water conditions and have become indicators of river health condition to aquatic ecologists. The presence and absence of some particular aquatic insect indicate the degree of pollution, though the specific causative physicochemical pollutant may be identified by physicochemical methods (Gupta \& Paliwal 2010). For a variety of reasons, aquatic insects are extremely important to the vitality of rivers and streams and thus can be viewed as surrogates for river and stream wealth. First, from a logistic standpoint they make good study specimens because they are abundant, readily surveyed and taxonomically rich. Since diversity and abundance of aquatic insects provides an indication of the overall health of the water body. Identifying the diversity and community composition of a sample of aquatic insect in a selected water bodies will help to determine the overall richness and abundance of the aquatic insect fauna within that stream. The aims of this study were: To categorise the aquatic insect diversity in Mae Tao and Mae $\mathrm{Ku}$ watersheds; and to assess the water quality status of Mae Tao and Mae Ku watersheds and how this influences aquatic insect diversity and richness.

\section{MATERIALS AND METHODS}

\section{STUDY AREA AND SAMPLING STATION}

Mae Tao and Mae Ku watersheds are located in northern Thailand. The area is surrounded by agricultural activities, community settlements and mining areas. The stream water is primarily used as a source of water for the communities. It also provides a daily source of fish and therefore income to the surrounding villagers. The five sampling sites are located along Mae Tao watershed and two are located in Mae Ku watershed, Mae Sot District, Tak Province (Figure 1). The locality information of each sampling site is shown in Table 1.

\section{AQUATIC INSECTS SAMPLING}

Aquatic insects were sampled using aquatic D-hand net with a dimension of $30 \times 30 \mathrm{~cm}$ frame, $250 \mu \mathrm{m}$ mesh, $50 \mathrm{~cm}$ length was used throughout the sampling. At each sampling locality, a stretch of approximately $50 \mathrm{~m}$ was chosen for collection of samples from the three target habitats - riparian vegetation, leaf litter, low gradient riffles and pools. The sampling time at each habitat was $3 \mathrm{~min}$. In each sampling period, three replicate samples were collected at each station, considering all possible microhabitats over representative sections of the stream. Samples were placed in white trays for sorting and screening of the aquatic insects. The aquatic insects were handpicked from the tray. Any non-aquatic insects caught were immediately returned to the stream. The content of each sample (net) was transferred into properlylabelled plastic containers, preserved in $80 \%$ ethanol and taken back to the laboratory for analysis. In the laboratory, aquatic insects were sorted on a Petri dish and identified to the family level using taxonomic keys by several authors (Dudgeon 1999; Wiggins 1996; Yule \& Sen 2004). Large aquatic insects were sorted by the naked eye whereas the sorting of the smaller ones was done under a dissecting microscope. All the sorted samples were kept in properlylabelled vials containing $80 \%$ ethanol.

\section{WATER QUALITY PARAMETERS}

The samples of water were collected from each sampling site immediately before the sampling of aquatic insects. Three replicates of selected physicochemical water quality parameters were recorded directly at the sampling site including; $\mathrm{pH}$, measured by a $\mathrm{pH}$-meter Waterproof Model Testr30; water temperature measured by a hand-held thermometer; dissolved oxygen (DO), measured by a $\mathrm{HACH}^{\circledR}$ Model sensION 6 DO meter and total dissolved solids (TDS) and conductivity were measured by a EURECH CyberScan CON110 conductivity/TDS meter. Water samples from each collecting period were stored in polyethylene bottles (500 $\mathrm{mL})$. The ammonia-nitrogen $\left(\mathrm{NH}_{4}-\mathrm{N}\right)$, sulfate $\left(\mathrm{SO}_{4}{ }^{2-}\right)$ and nitrate-nitrogen $\left(\mathrm{NO}_{3}-\mathrm{N}\right)$ were determined in accordance with the standard method procedures (APHA AWWA WPCF 1992). Alkalinity was measured by titration (APHA AWWA WPCF 1992). 


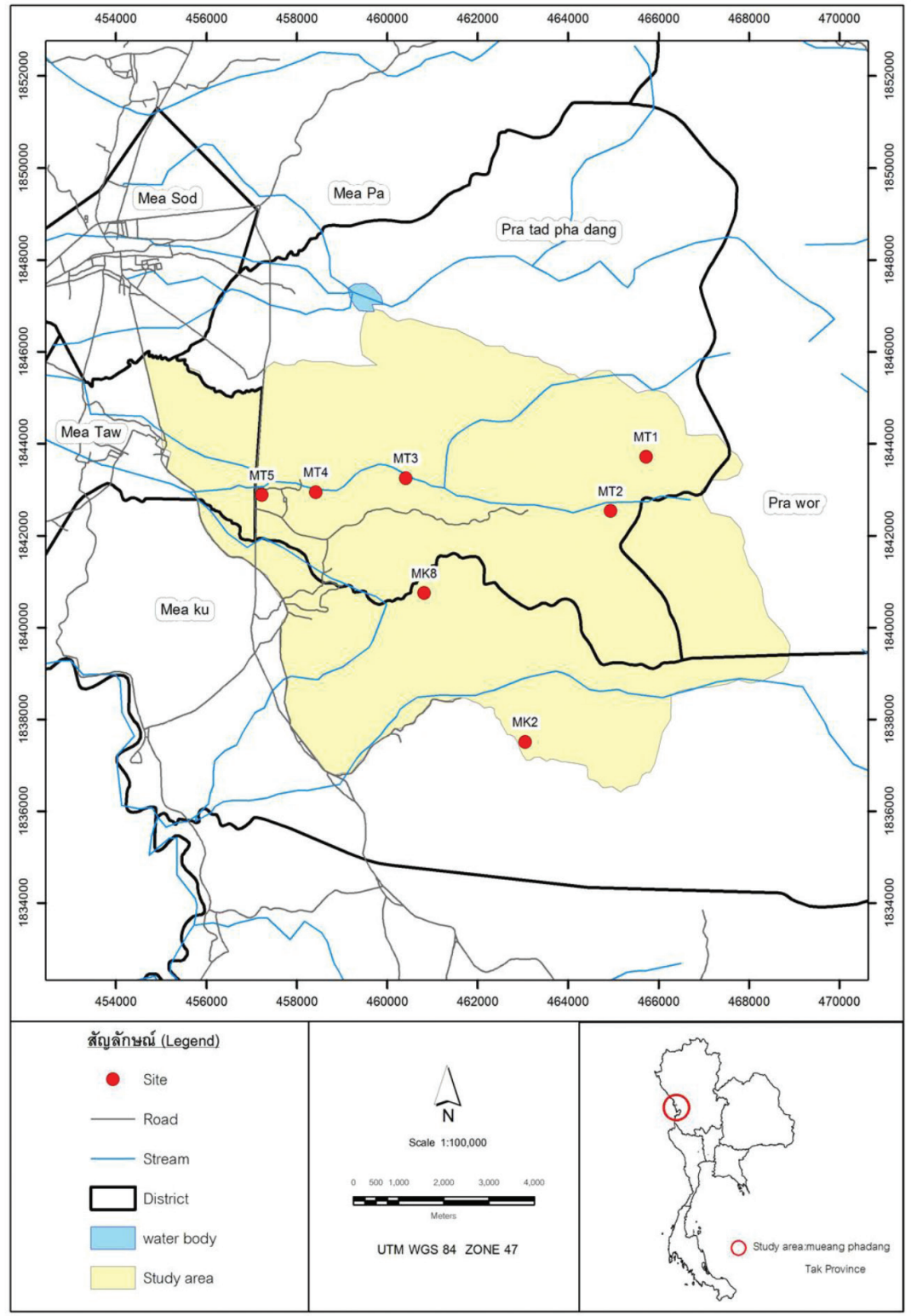

FIGURE 1. Map showing the sampling sites along Mae Tao (MT1-MT5) and Ame Ku (MK2, MK8) watersheds, Mae Sot District, Tak Province, northern Thailand

TABLE 1. Collection data for samples from Mae Tao and Mae Ku watersheds

\begin{tabular}{|c|c|c|c|c|}
\hline $\begin{array}{l}\text { Site } \\
\text { code }\end{array}$ & $\begin{array}{l}\text { Location } \\
\left({ }^{\circ} \mathrm{N},{ }^{\circ} \mathrm{E}\right)\end{array}$ & $\begin{array}{l}\text { Elevation } \\
\text { (m a.s.1.) }\end{array}$ & Description of substrates & Land use and surrounding environment \\
\hline MT1 & $40.55,40.71$ & 442 & $\begin{array}{l}\text { Man made concrete, gravel, woody } \\
\text { debris and other stable substrates }\end{array}$ & Forest and highland, Village both side \\
\hline MT2 & $39.90,40.28$ & 409 & $\begin{array}{l}\text { Boulders predominant, deep pool in the } \\
\text { middle, cobble, gravel and sand }\end{array}$ & $\begin{array}{l}\text { Mining area on side and forest other } \\
\text { side, cultivation on both side }\end{array}$ \\
\hline MT3 & $40.29,37.73$ & 234 & $\begin{array}{l}\text { Cobble predominant, deep pool in the } \\
\text { middle, gravel and sand }\end{array}$ & Village and cultivation on both side \\
\hline MT4 & $40.12,36.60$ & 230 & $\begin{array}{l}\text { Cobble predominant, deep pool in the } \\
\text { middle, gravel and sand }\end{array}$ & Village and cultivation on both side \\
\hline MT5 & $40.09,35.93$ & 224 & Muddy predominant, gravel and sand & Cultivation on both side \\
\hline MT2 & $37.18,39.22$ & 366 & Lime stone, gravel, woody debris & Forest and highland, Village both side \\
\hline MT8 & $38.93,37.96$ & 291 & Cobble, gravel, sand, woody debris & Forest and highland, Village both side \\
\hline
\end{tabular}




\section{DATA ANALYSES}

Analysis of variance (ANOVA) was used to test for statistical differences between the means of the physicochemical water quality parameters of the seven sampling sites. Duncan's Multiple Range Test (DMRT) was also used for multiple comparisons of the means of the physicochemical parameters in order to measure similarities of the sampling points. Spearman's rank correlation coefficient was used to determine the magnitude of the significance and nature of the relationship between variables. Diversity was computed using the Shannon- Wiener Index. The number of taxa (taxa richness or Taxa $S$ ) was measured by counting the number of aquatic insects families found in the samples. The aquatic insect taxonomic composition and physicochemical parameters were compared using the one-way Analysis of Variance (ANOVA). Spearman's correlation analysis was used to determine the magnitude of the significance and nature of the relationship between parameters.

\section{RESULTS}

\section{WATER QUALITY PARAMETERS}

Mean values of selected physicochemical parameters of water quality at Mae Tao and Mae $\mathrm{Ku}$ watershed from this study are presented in Table 2. Water temperature, dissolved oxygen and ammonia-nitrogen were not notably different during the period of study $(p>0.05)$ using ANOVA. Temperatures varied from 24.31 (MK2) to $27.25 \mathrm{C}^{\circ}$ (MK8). The lowest mean value of dissolved oxygen $(3.93 \mathrm{mg} / \mathrm{L})$ was found in the downstream station (MT5) and the highest values were observed in upper stream station $(\geq 4.13 \mathrm{mg} / \mathrm{L})$. Regarding the $\mathrm{pH}$, the water of Mae Tao and Mae $\mathrm{Ku}$ watersheds were slightly basic with low variation of the recorded figures ((8.03 (MT1)-8.75 (MK2)). The highest mean value of conductivity and total dissolved solids (587.71 $\mu \mathrm{S} / \mathrm{cm}, 315.10 \mathrm{mg} / \mathrm{L})$ was observed at MK8 and lowest was observed at MT1 $(297.05 \mu \mathrm{S} / \mathrm{cm}, 163.30 \mathrm{mg} / \mathrm{L})$, respectively. The mean concentration value of sulfate ranged from 15.33 (MT1) to $38.17 \mathrm{mg} / \mathrm{L}$ (MT5). The mean dissolved nutrients, nitrate-nitrogen and ammonia-nitrogen concentrations varied from 1.80 (MT1) to $2.98 \mathrm{mg} / \mathrm{L}$ (MK2, MK8) and 0.23 (MT1-MT3, MK8) to $0.29 \mathrm{mg} / \mathrm{L}$ (MT5), respectively. The mean alkalinity values ranged from 51.17 (MT1) to $82.73 \mathrm{mg} / \mathrm{L}$ (MT3).

\section{AQUATIC INSECT COMPOSITION AND ABUNDANCE}

A total of 8982 individual aquatic insects were recorded, distributed among 59 families with 9 orders belonging to Trichoptera (4108 individuals; $45.75 \%$ of total abundance), Ephemeroptera (1622 individuals; $18.06 \%$ of total abundance), Hemiptera (1208 individuals; $13.45 \%$ of total abundance), Odonata (864 individuals; $9.62 \%$ of total abundance), Diptera (736 individuals; $8.17 \%$ of total abundance), Coleoptera (413 individuals; $4.60 \%$ of total abundance), Megaloptera (15 individuals; $0.17 \%$ of total abundance), Lepidoptera (10 individuals; $0.11 \%$ of total abundance), Plecoptera (6 individuals; $0.07 \%$ of total abundance) (Figure 2; Table 3). The total number of taxa and individual recorded at MT1 to MT5, MK2 and MK8 were 38 (975), 35 (1507), 45 (1618), 39 (1371), 39 (2522), 22 (332) and 30 (657), respectively (Table 3). Hydropsychidae were presented at all sampling stations in high numbers (3082 individuals). Chironomidae was present at all sampling stations, but the high individual count (440) was present in the downstream area (MT5). Also, families Baetidae, Caenidae, Heptageiidae, Hydrophilidae, Gerridae, Nepidae, Libellulidae, Gomphidae, Platycnemididae, Corduliidae, Leptoceridae, Philopotamidae and Odontoceridae were present at all sampling stations.

\section{TAXA RICHNESS AND DIVERSITY}

Table 4 shows the significant variability in taxa richness (Taxa S) or number of families present $(F=2.348, p<0.05)$. MT3 showed the highest recorded Taxa $S$ of 33 families, whilst MK2 and MK8 had the lowest with 2 families (Table 4). Taxa richness calculations for Mae Tao and Mae $\mathrm{Ku}$ watersheds showed a range of 6.67 (MK2) to 23.00 (MT3) (Table 4). The results in Table 4 also showed that there was a significant difference in taxa richness between stations $(F=2.348, p<0.05)$. The Shannon-Wiener diversity index (H') showed a range of 1.01 (MK2) to 2.36 (MT3) (Table 4). These results also displayed a significant difference in Shannon-Wiener Index among sampling stations $(F=$ 3.293, $p<0.05$ ) (Table 4).

Table 5 shows that taxa richness (taxa $S$ ) had a considerable negative relationship with dissolved oxygen $(r=-0.347, p<0.05)$, nitrate-nitrogen $(r=-0.644, p<0.01)$ and ammonia-nitrogen $(r=-0.340, p<0.05)$ on the other hand it positively correlated with sulfate $(r=0.380$, $p<0.05)$. Meanwhile, Shannon-Wiener diversity index had a negative relationship with nitrate-nitrogen $(r=-0.497$, $p<0.01)$.

\section{DISCUSSION}

The physicochemical water quality parameters of Mae Tao and Mae $\mathrm{Ku}$ watersheds in the seven sampling stations were significantly different, except for water temperature, dissolved oxygen and ammonia-nitrogen level (Table 2). In a lotic ecosystem, especially streams, biological condition is strongly influenced by water chemistry and habitat quality (Bio et al. 2011). Low dissolved oxygen, high nitrate or phosphorous concentrations and low $\mathrm{pH}$ can cause reduced water quality. A desirable habitat quality is generally characterized by a heterogeneous habitat with both slow and fast moving water, woody debris, substrate variety, and well-vegetated, stable banks (Galuppo et al. 2007). Impairment of habitat and water chemistry can lead to the reduced diversity of aquatic macroinvertebrates (Hepp et al. 2013).

Trichoptera was the most abundant insect order in Mae Tao and Mae Ku watersheds (Figure 2). The immature 


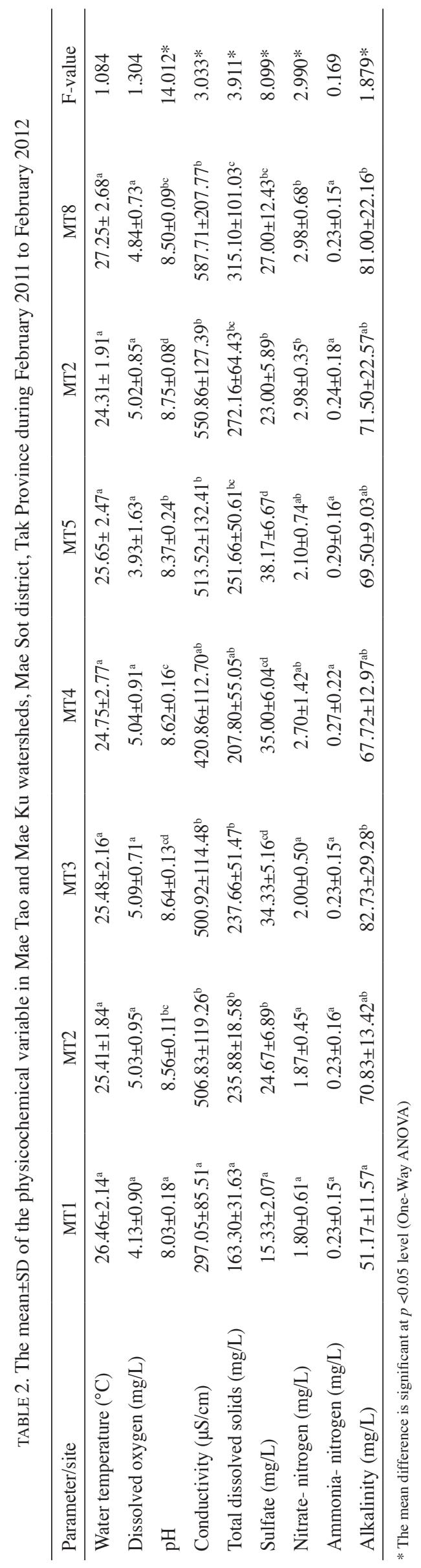




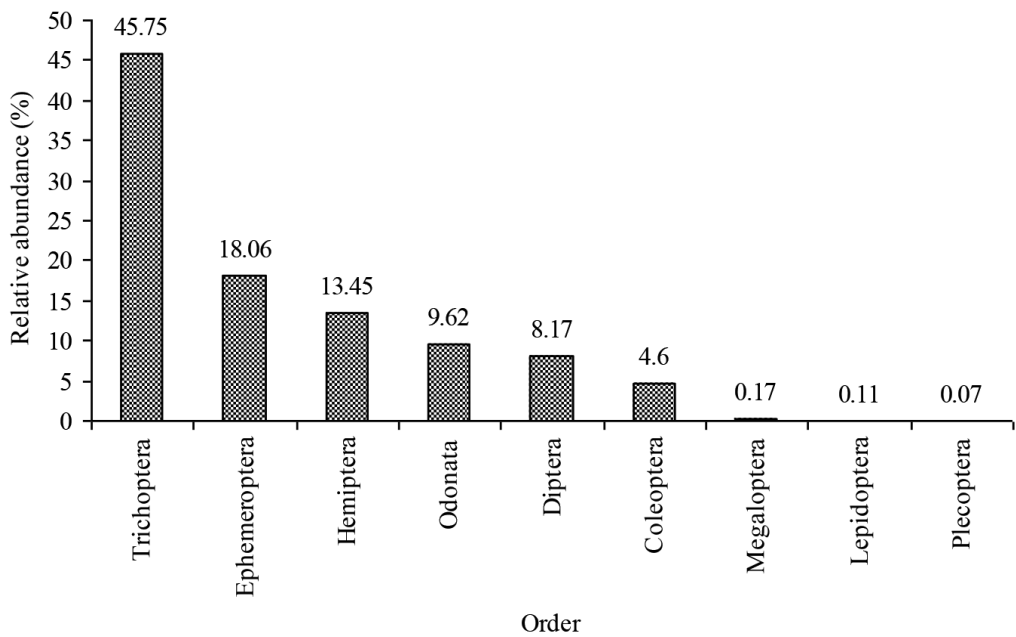

FIGURE 2. Relative abundance of aquatic insects per order, Mae Tao and Mae Ku watersheds, Mae Sot district, Tak Province during February 2011 to February 2012

TABLE 3. Aquatic insect abundance and richness in Mae Tao and Mae Ku watersheds, Mae Sot district, Tak Province during February 2011 to February 2012

\begin{tabular}{|c|c|c|c|c|c|c|c|c|}
\hline Taxa/site & MT1 & MT2 & MT3 & MT4 & MT5 & MT2 & MT8 & Total \\
\hline \multicolumn{9}{|l|}{ Ephemeroptera } \\
\hline Baetidae & 117 & 49 & 13 & 34 & 94 & 6 & 18 & 331 \\
\hline Caenidae & 51 & 35 & 47 & 21 & 37 & 6 & 59 & 256 \\
\hline Ephemerellidae & & 25 & 7 & 23 & 4 & & & 59 \\
\hline Ephemeridae & 5 & 1 & 96 & 5 & 7 & & & 114 \\
\hline Heptageniidae & 52 & 103 & 137 & 143 & 43 & 5 & 7 & 490 \\
\hline Leptophelebiidae & 9 & 148 & 76 & 114 & 9 & & 16 & 372 \\
\hline \multicolumn{9}{|l|}{ Odonata } \\
\hline Aeshnidae & & & & & & & 3 & 3 \\
\hline Calopterygidae & & 2 & 4 & 15 & 2 & & & 23 \\
\hline Chlorocyphidae & 2 & 6 & 17 & 11 & 1 & & 4 & 41 \\
\hline Coenagrionidae & & 5 & 2 & 14 & 10 & 1 & 6 & 38 \\
\hline Corduliidae & 2 & 7 & 19 & 4 & 5 & 2 & 2 & 41 \\
\hline Euphaeidae & 6 & 127 & 7 & 7 & & & & 147 \\
\hline Gomphidae & 1 & 25 & 223 & 14 & 30 & 1 & 10 & 304 \\
\hline Libellulidae & 2 & 76 & 15 & 33 & 17 & 6 & 8 & 157 \\
\hline Platycnemididae & 4 & 3 & 10 & 27 & 31 & 3 & 21 & 99 \\
\hline Platystictidae & 1 & & 10 & & & & & 11 \\
\hline \multicolumn{9}{|l|}{ Plecoptera } \\
\hline Perlidae & & 5 & & 1 & & & & 6 \\
\hline \multicolumn{9}{|l|}{ Hemiptera } \\
\hline Aphelocheiridae & & & 47 & & & & & 47 \\
\hline Corixidae & 1 & & & & 5 & 2 & & 8 \\
\hline Gerridae & 8 & 4 & 135 & 129 & 171 & 90 & 77 & 614 \\
\hline Helotrephidae & & & 2 & 3 & & & & 5 \\
\hline Hydrometridae & 1 & 1 & 19 & 40 & 11 & & 3 & 75 \\
\hline
\end{tabular}


TABLE 3. Continued.

\begin{tabular}{|c|c|c|c|c|c|c|c|c|}
\hline Taxa/site & MT1 & MT2 & MT3 & MT4 & MT5 & MT2 & MT8 & Total \\
\hline Mesoveliidae & & & & 12 & 2 & & & 14 \\
\hline Naucoridae & 3 & 2 & 195 & 90 & & & & 290 \\
\hline Nepidae & 4 & 8 & 21 & 25 & 7 & 6 & 16 & 87 \\
\hline Notonectidae & 1 & & 1 & & 1 & & & 3 \\
\hline Veliidae & 15 & 2 & 20 & 18 & & 9 & 1 & 65 \\
\hline \multicolumn{9}{|l|}{ Megaloptera } \\
\hline Corydalidae & 5 & 8 & 1 & & & & 1 & 15 \\
\hline \multicolumn{9}{|l|}{ Coleoptera } \\
\hline Dryopidae & & & & 2 & & & & 2 \\
\hline Dytiscidae & & 1 & 13 & & 1 & 4 & 1 & 20 \\
\hline Elmidae & & & 52 & 17 & 14 & & 3 & 86 \\
\hline Gyrinidae & & & 71 & 52 & & & & 123 \\
\hline Hydraenidae & & & 69 & 31 & 2 & & 9 & 111 \\
\hline Hydrophilidae & 6 & 6 & 26 & 20 & 1 & 1 & 1 & 61 \\
\hline Psephenidae & 1 & & & & & & & 1 \\
\hline Scirtidae & 1 & 1 & 1 & 2 & 2 & & 1 & 8 \\
\hline Staphylinidae & & & & & & 1 & & 1 \\
\hline \multicolumn{9}{|l|}{ Diptera } \\
\hline Athericidae & 4 & 1 & 1 & 1 & 3 & & & 10 \\
\hline Ceratopogonidae & & 1 & & & 8 & & 1 & 10 \\
\hline Chironomidae & 39 & 14 & 21 & 11 & 440 & 5 & 12 & 542 \\
\hline Culicidae & & & 20 & & 4 & 7 & & 31 \\
\hline Dixidae & 1 & & & & 4 & & & 5 \\
\hline Empididae & 4 & & & & & & & 4 \\
\hline Muscidae & & 1 & & & 10 & & & 11 \\
\hline Sciomyzidae & & & & 2 & & & & 2 \\
\hline Simuliidae & 13 & 7 & 1 & 1 & 7 & & & 29 \\
\hline Stratiomyidae & 2 & & 1 & & & & 2 & 5 \\
\hline Tanyderidae & 1 & & & & & & & 1 \\
\hline Tipulidae & 16 & 20 & 28 & 11 & 6 & & 5 & 86 \\
\hline \multicolumn{9}{|l|}{ Lepidoptera } \\
\hline Crambidae & & & 1 & & 8 & 1 & & 10 \\
\hline \multicolumn{9}{|l|}{ Trichoptera } \\
\hline Calamoceratidae & 26 & & & 4 & & & & 30 \\
\hline Glossosomatidae & 91 & 23 & 5 & 2 & 24 & & & 145 \\
\hline Helicopsychidae & & & 2 & & & & & 2 \\
\hline Hydropsychidae & 269 & 596 & 108 & 285 & 1354 & 131 & 339 & 3082 \\
\hline Hydroptilidae & & & 1 & & & & 1 & 2 \\
\hline Lepidostomatidae & 20 & & 1 & & 4 & & & 25 \\
\hline Leptoceridae & 53 & 4 & 10 & 28 & 2 & 29 & 3 & 129 \\
\hline Odontoceridae & 117 & 3 & 27 & 56 & 7 & 1 & 26 & 237 \\
\hline Philopotamidae & 21 & 187 & 35 & 63 & 134 & 15 & 1 & 456 \\
\hline Total number of individual & 975 & 1507 & 1618 & 1371 & 2522 & 332 & 657 & 8982 \\
\hline Number of families & 38 & 35 & 45 & 39 & 39 & 22 & 30 & \\
\hline
\end{tabular}


stages of Trichoptera all live in freshwater and flourish in running waters (i.e. rivers) greater than in any other freshwater body (Daly et al. 1998; Wiggins 1996). The family Hydropsychidae was the most persistent and the most abundant (Table 3). This was followed in abundance by Gerridae, Chironomidae, Heptageniidae and Philopotamidae. In the present study the parameters like dissolved oxygen, sulfate and nutrient have direct impact on the growth of biotic communities. However the other physicochemical variables have a direct as well as an indirect effect on the biological diversity (Roland et al. 2012). The physicochemical parameters are useful in detecting the effect of pollution on the water quality, but changes in trophic conditions of water are reflected in the biological community structure including species pattern, distribution and diversity (Ishas \& Khan 2013). The most common physical assessment of water quality is the measurement of temperature. Temperature impacts both the chemical and biological characteristics of surface water. In the present study there was only a slight temperature variation in Mae Tao and Mae $\mathrm{Ku}$ watershed. Water temperature was not indirect correlation with taxa richness and diversity in this study. The higher water temperatures probably favored the densities and diversity of Hydropsychidae in the Mae Tao and Mae $\mathrm{Ku}$ watersheds. Temperature is one of the major factors determining the distribution of Hydropsychidae, where most of the species exhibit higher densities in warmer waters (Kimura et al. 2008). Trichopterans are especially sensitive to decrease in water quality (Dohet 2002; Guilpart et al. 2012). Ephemeroptera, Plecoptera and Trichoptera are often used as indicators of good water quality (Crisci-Bispo et al. 2007; Qu et al. 2010). One family in order Plecoptera was recorded in this study. Diversity of Plecoptera families is generally low in tropical Asian streams (Hamid \& Rawi 2011). However, studies of rivers in Thailand and the Philippines have showed the presence of Perlidae, Nemouridae, Leuctridae and Peltoperlidae (Boonsoong \& Sangpradub 2008). The absence of the families in Mae Tao and Mae Ku watershed could be due to unfavorable conditions (i.e. temperature) for its growth and reproduction. The Plecopteran order is typical of cooler, more northern latitudes (Sivec \& Yule 2004).

$\mathrm{pH}$ is the measure of the intensity of acidity or alkalinity and the concentration of hydrogen ions in water. $\mathrm{pH}$ affects the dissolved oxygen level of the water, photosynthesis of aquatic organisms (phytoplankton) and the sensitivity of these organisms to pollution, parasites and diseases (Ngodhe et al. 2014). A change in pH also affects aquatic life indirectly by altering other aspects of water chemistry. In this study, the $\mathrm{pH}$ showed a variation among sampling stations, however, displayed a direct correlation to richness and diversity (Table 5) which implies that many species favored slightly alkaline $\mathrm{pH}$ in basic habitat. The USEPA (1986) indicated that a $\mathrm{pH}$ range of 6.5 to 9.0 provides adequate protection for the life of freshwater fish and bottom-dwelling macroinvertebrates. Scheibler et al. (2014) reported that taxa richness, density of invertebrates and diversity increased along a river continuum with increases in $\mathrm{pH}$, hardness and nutrients.

The concentration of dissolved oxygen (DO) is one of the most important parameter to indicate water purity and to determine the distribution of various aquatic insect groups (Wahizatul et al. 2011). In this study, dissolved oxygen concentration negatively affected taxa richness. Paaijmans et al. (2008) noted that suspended particles in the water absorb heat thus they could increase water temperatures. This, in turn, could reduce the oxygen content of the water since warm water holds less dissolved oxygen than cold (Mandal 2014). Aquatic insects, especially the bottom-dwellers, are sensitive to temperature and will move to areas in stream where they find their optimal temperature (Hering et al. 2009). If temperatures are outside their optimal range for a prolonged period of time, organisms can become stressed and die. A study of the diversity and abundance of aquatic macroinvertebrates in a stream in Brazil reports that the sampling station with the lowest temperature and highest dissolved oxygen level had the highest Shannon-Weiner diversity index (Silva et al. 2009). Stoyanova et al. (2014) found that gill-breathing aquatic insects (e.g. caddisflies, mayflies and stoneflies) are affected by conditions that reduce the dissolved oxygen of the water, like pollution; therefore the presence of

TABLE 4. Summary of the biological indices at the study sites of Mae Tao and Mae Ku watersheds, Mae Sot district, Tak Province during February 2011 to February 2012. Values are Mean \pm SD (minimum and maximum values in parentheses)

\begin{tabular}{lll}
\hline Sites & \multicolumn{1}{c}{ Taxa richness $($ Taxa S) } & \multicolumn{1}{c}{$\mathrm{H}^{\prime}$} \\
\hline MT1 & $15.17 \pm 6.55^{\mathrm{abc}}(8.00-22.00)$ & $1.83 \pm 0.61^{\mathrm{bc}}(1.19-2.47)$ \\
MT2 & $15.83 \pm 7.19^{\mathrm{abc}}(8.00-23.00)$ & $1.73 \pm 0.46^{\mathrm{abc}}(1.25-2.21)$ \\
MT3 & $23.00 \pm 9.47^{\mathrm{c}}(13.00-33.00)$ & $2.36 \pm 0.45^{\mathrm{c}}(1.90-2.83)$ \\
MT4 & $17.67 \pm 11.67^{\mathrm{bc}}(5.00-30.00)$ & $1.96 \pm 0.99^{\mathrm{bc}}(0.93-2.99)$ \\
MT5 & $16.00 \pm 8.22^{\mathrm{abc}}(7.00-25.00)$ & $1.53 \pm 0.17^{\mathrm{ab}}(1.36-1.71)$ \\
MK2 & $6.67 \pm 4.18^{\mathrm{a}}(2.00-11.00)$ & $1.01 \pm 0.75^{\mathrm{a}}(0.23-1.80)$ \\
MK8 & $11.17 \pm 8.28^{\mathrm{ab}}(2.00-20.00)$ & $1.21 \pm 0.59^{\mathrm{ab}}(0.58-1.82)$ \\
F-value & $2.348^{*}$ & $3.293^{*}$ \\
\hline
\end{tabular}

* The mean difference is significant at $p<0.05$ level (One-Way ANOVA); H' = Shannon-Weaver diversity index 
TABLE 5. Spearman's correlation coefficient between selected physicochemical factors and aquatic insect diversity and richness in Mae Tao and Mae Ku watersheds, Mae Sot district,

Tak Province during February 2011 to February 2012

\begin{tabular}{lcc}
\hline Parameter & Taxa S & H' $^{\prime}$ \\
\hline Water temperature $\left({ }^{\circ} \mathrm{C}\right)$ & -0.124 & -0.105 \\
Dissolved oxygen $\left(\mathrm{mg} \mathrm{l}^{-1}\right)$ & $-0.347 *$ & -0.138 \\
$\mathrm{pH}$ & -0.201 & -0.059 \\
Conductivity $\left(\mu \mathrm{cm}^{-1}\right)$ & 0.121 & -0.068 \\
Total dissolved solids $\left(\mathrm{mg} \mathrm{l}^{-1}\right)$ & 0.128 & -0.023 \\
Sulfate $\left(\mathrm{mg} \mathrm{l}^{-1}\right)$ & $0.380 *$ & 0.285 \\
Nitrate Nitrogen $\left(\mathrm{mg} \mathrm{l}^{-1}\right)$ & $-0.644 * *$ & $-0.497 * *$ \\
Ammonia nitrogen $\left(\mathrm{mg} \mathrm{l}^{-1}\right)$ & $-0.340 *$ & -0.292 \\
Alkalinity $\left(\mathrm{mg} \mathrm{l}^{-1}\right)$ & -0.120 & -0.111 \\
\hline
\end{tabular}

*. Correlation is significant at the 0.05 level (2-tailed).

**. Correlation is significant at the 0.01 level (2-tailed).

caddisflies, mayflies and stoneflies indicates high stream quality.

Electrical conductivity is a function of total dissolved solids known as ion concentration, which determines the quality of water (Tariq et al. 2006). Electrical conductivity or total dissolved solids measure how much total salt (inorganic ions such as sodium, chloride, magnesium and calcium) is present in the water. Electrical conductivity itself is not a human or aquatic health concern, but because it is easily measured, it can serve as an indicator of other water quality problems. If the conductivity of a stream suddenly increases, it indicates that there is a source of dissolved ions in the vicinity. Therefore, conductivity measurements can be used as an efficient way to locate potential water quality problems (Siddaramu \& Puttaiah 2013). All natural waters contain some dissolved solids due to the dissolution and weathering of rock and soil. Some but not all dissolved solids act as conductors and can contribute to conductance. Waters with high total dissolved solids are unpalatable and potentially unhealthy. In this study, electrical conductivity and total dissolved solids showed little variation between sampling stations. Electrical conductivity and total dissolved solids did not correlated with taxa richness (taxa S) nor the ShannonWeiner diversity index in this study.

Sulfate is widely distributed in nature and may be present in natural waters at concentrations ranging from a few to several hundred milligrams per liter. Anthropogenic sources of sulfate may come from mine drainage wastes. In coalfield streams, total dissolved solids are most often dominated by the dissolved ions $\mathrm{SO}_{4}{ }^{2-}$ and $\mathrm{HCO}_{3}^{-}$(Pond et al. 2008). In this study, the sulfate content varied in all sampling stations and positively correlated with taxa richness. Alkalinity is measured to determine the ability of river to resist changes in $\mathrm{pH}$. Alkalinity values of 20-200 $\mathrm{mg} / \mathrm{L}$ are common in fresh water ecosystems. Alkalinity below $10 \mathrm{mg} / \mathrm{L}$ indicates poorly buffered rivers. These rivers are least capable of resisting changes in $\mathrm{pH}$, therefore they are more susceptible to problems which occur as a result of acidic pollutants (Biggs 1995). The concentration of nitrate-nitrogen at all the sites was in trace amounts. The nitrate concentration depends on the activity of nitrifying bacteria which in turn gets influenced by the presence of dissolved oxygen. The taxa richness and diversity of aquatic insects dwelling the Mae Tao and Mae $\mathrm{Ku}$ watersheds correlated negatively with nitrate-nitrogen. The concentration of ammonia-nitrogen also negatively correlated with diversity of aquatic insects (Table 5).

The diversity values for real communities are often found to fall between 1.0 and 6.0 (Stiling 1996), this means that diversity at all the sampling stations of Mae Tao and $\mathrm{Mae} \mathrm{Ku}$ watersheds were relatively low since none had an H' value higher than 2.5 (Table 4). Wilhm and Dorris (1968) set the diversity index of less than 1 for highly polluted, 1-3 for moderately polluted and greater than 4 for unpolluted water bodies. All sampling stations in this study (Table 4) were shown as moderately polluted using this scale. Aquatic insect diversity in Mae Tao and Mae $\mathrm{Ku}$ watersheds could have been affected by the presence of pollution in the river.

\section{CONCLUSION}

From the results throughout this study period, a total of 59 families representing 9 orders were recorded. Hydropsychidae were present at all sampling stations in the high number of individual. Chironomidae was present at all sampling stations, but the high individual count was present in the downstream area. Also, families Baetidae, Caenidae, Heptageiidae, Hydrophilidae, Gerridae, Nepidae, Libellulidae, Gomphidae, Platycnemididae, Corduliidae, Leptoceridae, Philopotamidae and Odontoceridae were present at all sampling stations. This indicates the richness and diverse group of aquatic insects in the study area. It reinforces to the fact that the habitat quality is most suitable for insects to breed and multiply under the natural ecosystem. Furthermore, the river's environmental factors had directly and/or indirectly affected aquatic insect assemblages, showing that aquatic insects were useful indicators of water quality in the Mae Tao and Mae $\mathrm{Ku}$ watershed. All sampling stations in this study came out as moderately polluted by indication of diversity index. 


\section{ACKNOWLEDGEMENTS}

Financial support for this research was given through a scholarship and grants of the Graduate School, Kasetsart University year 2012 to Ampon Payakka. In addition, this research was supported by the Thailand Research Fund (MRG5480221).

\section{REFERENCES}

APHA, AWWA, WPCF. 1992. Standard Method for the Examination of Water and Wastewater. 18th ed. American Public Health Association. Washington DC.

Arimoro, F.O. \& Ikomi, R.B. 2008. Ecological integrity of upper Warri River, Niger Delta using aquatic insects as bioindicators. Ecological Indicator 395: 1-7.

Aweng, E.R., Ismid, M.S. \& Maketab, M. 2011. The effect of land uses on physicochemical water quality at three rivers in Sungai Endau watershed, Kluang, Johor, Malaysia. Australian Journal of Basic and Applied Sciences 5(7): 923-932.

Borisko, J.P., Kilgour, B.W., Stanfield, L.W. \& Jones, F.C. 2007. An evaluation of rapid bioassessment protocols for stream benthic invertebrates in Southern Ontario, Canada. Water Quality Research Journal of Canada 42(3): 184-193.

Biggs, B.J.F. 1995. Relationship between benthic biota and hydrological indices in New Zealand streams. Freshwater Biology 38: 327-342.

Bio, A., Vieira, N., Costa, M.J. \& Valente, A. 2011. Assessment of habitat and water quality of the Portuguese Febros River and one of its tributaries. Limnetica 30(1): 103-116.

Boonsoong, B. \& Sangpradub, N. 2008. Diversity of stream benthic macroinvertebrates at the Loei River and adjacent catchments, northeastern Thailand. KKU Science Journal 36(Supplement):107-121.

Buss, D.F. \& Vitorino, A.S. 2010. Rapid bioassessment protocols using benthic macroinvertebrates in Brazil: Evaluation of taxonomic sufficiency. Journal of the North American Benthological Society 29(2): 562-571.

Cairns, Jr. \& Prall, A.R. 1993. A history of biological monitoring using benthos macroinvertebrates. In Freshwater Biomonitoring and Benthic Macroinvertebrates, edited by Rosenberg, D.M. \& Resh, V.H. New York: Chapman and Hall. pp. 159-194.

Chae, S.J., Purstela, N., Johnson, E., Derock, E.S., Lawler, P. \& Madigan, J.E. 2000. Infection of aquatic insects with trematode metacercariae carrying Ehrilichia risticii, the case of the Potomac house fever. Journal of Medical Entomology 37: 619-625.

Crisci-Bispo, V.L., Bispo, P.C. \& Froehlich, C.G. 2007. Ephemeroptera, Plecoptera and Trichoptera assemblages in litter in a mountain stream of the Atlantic rainforest from Southeastern Brazil. Revista Brasileira de Zoologia 24: 545-551.

Daly, H.V., Doyen, J.T. \& Purcell, A.H. 1998. Introduction to Insect Biology and Diversity. New York: Oxford University Press, Inc.

Dohet, A. 2002. Are caddisflies an ideal group for the biological assessment of water quality in streams? In Proceedings of the Xth International Symposium on Trichoptera, edited by Mey, W. Germany: Potsdam. pp. 507-520.

Dudgeon, D. 1999. Tropical Asian Streams Zoobenthos, Ecology and Conservation. Hong Kong: Hong Kong University Press.

Galuppo, N., Maci, S., Pinna, M. \& Basset, A. 2007. Habitat types and distribution of benthic macroinvertebrates in a transitional water ecosystem: Alimini Grande (Puglia, Italy). Transitional Waters Bulletin 4: 9-19.

Guilpart, A., Roussel, J.M., Aubin, J., Caquet, T., Marle, M. \& Bris, H.L. 2012. The use of benthic invertebrate community and water quality analyses to assess ecological consequences of fish farm effluents in rivers. Ecological Indicators 23: 356-365.

Gupta, M. \& Paliwal, A. 2010. Role of aquatic insects of water quality in related to physico-chemical parameters in Yamuna River at District Firozabad (U.P.). Advanced Biomedical Research 1(1): 71-74.

Hamid, S.A. \& Rawi, C.S.M. 2011. Stoneflies (Insecta: Plecoptera) in Malaysian tropical rivers: Diversity and seasonality. Journal of Entomology and Nematology 3(2): 030-036.

Hepp, L.U., Restello, R.M. \& Milesi, S.V. 2013. Distribution of aquatic insects in urban headwater streams. Acta Limnologica Brasiliensia 25(1): 1-9.

Hering, D., Schmidt-Kloiber, A., Murphy, J., Lücke, S., ZamoraMuńoz, C., López-Rodŕguez, M.J., Huber, T. \& Graf, W. 2009. Potential impact of climate change on aquatic insects: A sensitivity analysis for European caddisflies (Trichoptera) based on distribution patterns and ecological preferences. Aquatic Science 71: 3-14.

Ishas, F. \& Khan, A. 2013. Aquatic biodiversity as an ecological indicators for water quality criteria of River Yamuna in Doon Valley, Uttarakhand, India. World Journal of Fish and Marine Sciences 5(3): 322-334.

Kimura, G., Inoue, E. \& Hirabayashi, K. 2008. Seasonal abundance of adult caddisfly (Trichoptera) in the middle reaches of the Shinano River in Central Japan. In Proceedings of the Sixth International Conference on Urban Pests, edited by Robinson, W.H. \& Bajomi, D. Hungary: OOK-Press Kft.

Mandal, H.K. 2014. Assessment of wastewater temperature and its relationship with turbidity. Recent Research in Science and Technology 6(1): 258-262.

Merritt, R.W. \& Cummins, K.W. 1996. Aquatic Insects of the North America. Dubuque: Kendall Hunt Publishing Company.

Ngodhe, S.O., Raburu, P.O. \& Achieng, A. 2014. The impact of water quality on species diversity and richness of macroinvertebrates in small water bodies in Lake Victoria Basin, Kenya. Journal of Ecology and the Natural Environment 6(1): 32-41.

Oliveira, S.V. \& Cortes, R.M.V. 2006. Environmental indicators of ecological integrity and their development for running waters in northern Portugal. Limnetica 25(1-2): 479-498.

Paaijmans, K.P., Takken, W., Githeko, A.K. \& Jacobs, A.F. 2008. The effect of water turbidity on the near-surface water temperature of larval habitats of the malaria mosquito Anopheles gambiae. International Journal of Biometeorology 52: 747-753.

Pennak, W.R. 1978. Fresh-water Invertebrates of United States. New York: Willy-Interscience Publishing.

Pond, G.J., Passmore, M.E., Borsuk, F.A., Reynolds, L. \& Rose, C.J. 2008. Downstream effects of mountaintop coal mining: Comparing biological conditions using family-and genuslevel macroinvertebrate bioassessment tools. Journal of North American Benthological Society 27(3): 717-737.

Qu, X., Wu, N., Tang, T., Cai, Q. \& Park, Y.S. 2010. Effects of heavy metals on benthic macroinvertebrate communities in high mountain streams. Annales de Limnologie - International Journal of Limnology 46: 291-302. 
Roland, F., Huszar, V.L.M., Farjalla, V.F., Enrich-Prast, A., Amado, A.M. \& Ometto, J.P.H.B. 2012. Climate change in Brazil: Perspective on the biogeochemistry of inland waters. Brazilian Journal of Biology 72(3) (suppl.): 709-722.

Rosenberg, D.M. \& Resh, V.H. 1993. Freshwater Biomonitoring and Benthic Macroinvertebrates. New York: Chapman and Hall.

Resh, V.H., Myers, M.J. \& Hannaford, M.J. 1996. Macroinvertebrates as biotic indicators of environmental quality. In Method in Stream Ecology, edited by Hauer, F.R. \& Lamberti, G.A. New York: Academic Press. pp. 647-667.

Scheibler,E.E., Claps, M.C.\& Roig-Junent, S.A. 2014. Temporal and altitudinal variations in benthic macroinvertebrate assemblages in an Andean river basin of Argentina. Journal of Limnology 73(1): 92-108.

Siddaramu, D. \& Puttaiah, E.T. 2013. Physicochemical characteristics of Balagala Kere and Purali Kere of Shimoga District, Karnataka, India. International Journal of Advanced Research 1(8): 313-321.

Silva, F.L., Moreira, D.C., Ruiz, S.S. \& Bochini, G.L. 2009. Diversity and abundance of aquatic macroinvertebrates in a lotic environment in Midwestern São Paolo State, Brazil. Ambi-Agua, Taubaté 4(1): 37-44.

Sivec, I. \& Yule, C.M. 2004. Insecta: Plecoptera. In Freshwater Invertebrates of the Malaysian Regio, edited by Yule, C.M. \& Sen, Y.H. Selangor: Aura Productions Sdn. Bhd.

Stiling, P.D. 1996. Ecology: Theories and Applications. 2nd ed. New Jersey: Prentice Hall.

Stoyanova, T., Vidinova, Y., Yaneva, I., Tyufekchieva, V., Parvanov, D., Traykov, I. \& Bogoev, V. 2014. Ephemeroptera, Plecoptera and Trichoptera as indicators for ecological quality of the Luda Reka River, Southwest Bulgaria. Acta Zoologica Bulgarica 66(2): 255-260.

Suhaila, A.H., Che Salmah, M.R. \& Nurul Huda, A. 2014. Seasonal abundance and diversity of aquatic insects in rivers in Gunung Jerai Forest Reserve, Malaysia. Sains Malaysiana 43(5): 667-674.
Tariq, M., Ali, M. \& Shah, Z. 2006. Characteristics of industrial effluents and their possible impacts on quality of underground water. Soil \& Environmental 25(1): 64-69.

United States Environmental Protection Agency (USEPA). 1986. Quality Criteria for Water. Office of Water Regulations and Standards. Washington, DC EPA/440/5-86-001.

Wahizatul, A.A., Long, S.H. \& Ahmad, A. 2011. Composition and distribution of aquatic insect communities in relation to water quality in two freshwater streams of Hulu Terengganu, Terengganu. Journal of Sustainability Science and Management 6(1): 148-155.

Wiggins, G.B. 1996. Larvae of the North American Caddisfly Genera (Trichoptera).2nd ed. Toronto: University of Toronto Press.

Wilhm, J.L. \& Dorris, T.C. 1968. Biological parameters of water quality criteria. Bioscience 18: 477-481.

Xu, M., Wang, Z., Duan, X. \& Pan, B. 2014. Effects of pollution on macroinvertebrates and water quality bio-assessment. Hydrobiologia 729: 247-259.

Zarei, H. \& Bilondi, M.P. 2013. Factor analysis of chemical composition in the Karoon River basin, southwest of Iran. Applied Water Science 3: 753-761.

Faculty of Liberal Arts and Science

Kasetsart University, Kamphaeng Saen Campus

Nakhon Pathom Province, 73140

Thailand

*Corresponding author; email: faastop@ku.ac.th

Received: 1 January 2015

Accepted: 22 January 2015 